nomson

glyndwhr

Glyndŵr University

Glyndŵr University Research Online

Theology

Theology

$1-1-2008$

\title{
Attitudes and Values of Adolescent Europeans towards Europeanisation
}

H-G Ziebertz

William K. Kay

Glyndwr University, w.kay@glyndwr.ac.uk

Follow this and additional works at: http://epubs.glyndwr.ac.uk/theo

Part of the Religious Thought, Theology and Philosophy of Religion Commons

This is the author's pre print version of the article after peer review, produced by permission of the publisher. The article was originally published in the Journal of Empirical Theology in 2008. The published version is available free at http://www.brill.nl/jet

\section{Recommended Citation}

Ziebertz, H-G. \& Kay, W. K. (2008) "Attitudes and Values of Adolescent Europeans towards Europeanisation”. Journal of Empirical Theology, 21 (2), 209-239 (31)

This Article is brought to you for free and open access by the Theology at Glyndŵr University Research Online. It has been accepted for inclusion in Theology by an authorized administrator of Glyndŵr University Research Online. For more information, please contact d.jepson@glyndwr.ac.uk. 


\title{
Attitudes and Values of Adolescent Europeans towards Europeanisation
}

\author{
Hans-Georg Ziebertz, University of Würzburg, Germany \\ William K Kay, Glyndwr University, United Kingdom
}

\begin{abstract}
Based on original empirical data collected from adolescents in Europe ( $N=9003)$ this paper focuses on the lifeworlds of young people. It analyses negative and positive patterns of attitude and combines them with further concepts: first, personal life perspectives, various key values and political attitudes, second, religious attitudes towards church(es), religions, world views and religious education. Technically, the attitude towards Europe acts as the dependent variable whereas the remaining concepts are used as independent variables. The empirical results show Turkish and Polish adolescents are more critical of Europe than adolescents living in "old" Europe. Furthermore, the data show that those who have negative expectations about their personal futures and follow a more traditional religious world view are likely also to be Eurosceptical.
\end{abstract}

In what, by historical standards, is a very short time, influential political and administrative leaders within Europe from about the mid-1980s onwards set out to create a shared economical, political and juridical area (Davies, 1996). As a result Europe now organizes the education of the young uniformly (Bologna declaration) and creates widespread opportunities for student exchange (Erasmus, Socrates programs). At the same time, Europe is characterised by diversity, and unity and diversity clearly exist in a relationship of tension. Beyond all attempts to shape the shared human world inhabited by Europeans - what might be called its "anthroposphere" - Europe is also integrated into the vast process of globalisation. However one of the unexpected effects of globalisation is to show that politics has reached its regulatory limits. In the discussion and analysis that follows we assume that young people's expectations are influenced by factors concerned with their security (economic, personal and political) and with their assessment of the likely material conditions of their lives. We start with a theoretical introduction (1) and a description of the design of the study (2). Subsequently, we explain the empirical results (3) and end with a discussion and reflection (4).

\section{$1 \quad$ Europeanisation and globalisation}

Europe is not an island cut off from the world, but is involved in a worldwide process of globalisation. On the one hand globalisation describes the breaking down of local, regional, and national boundaries, for example in economic action, in scientific discourse, in cultural patterns, and to some degree in political decisions (Weber 2001). The basic principles and perspectives of these no longer allow themselves to be limited to the framework of given national boundaries, but rather they will take their orientation from a global perspective. Certainly it is easiest for national economies to work globally (Albrow 1998; Sykes/Palier/Prior 2001; Scholte 2000). Public debate shows concern with globalization, 
however, because of the direct influence on the lives of ordinary people of economic forces outside the control of national politics (Stieglitz 2003). Without a doubt, globalisation has its advantages. Today we can have use of communication technology which helps us to stay in contact around the globe at anytime (Friedman, 2006). On the other hand there are genuine problems which can be seen in industrial relocation, product homogeneity and standardisation. Globalisation will not be adequately understood if it is conceptualized exclusively and simply as a broadening of perspective, one that results from cultural expansion. This is why, alongside the term globalization the term "glocalisation" was coined, in which global and local are brought together (Amin/Thrift 1994).

The process of the joining together of Europe is, in some respects, perpendicular to globalization. Its political mechanisms equip Europe for functioning effectively against global competition. The political mechanisms have ensured improvements in the quality of science, education, technological advances, cultural exchange on many levels, police networking and jurisdiction, and so on (Ducatel/Webster/Herrmann 2000). What is currently occurring in Europe is - from a global perspective - a regional collective initiative. Strategies for joining in global power play with North America or the Pacific Rim countries are helped by the integration of the European nations. However, the competence of individuals to orient themselves globally is quite unconnected from what the European Union as a whole can do. In fact, for many ordinary people within the EU, European institutions are already far away. Added to this is the fact that this Europe is not uniform. Where can the identity of Europe itself be found? And how can we express the identity of individual Europeans?

\section{Globalisation and Glocalisation}

According to Hermans (2001) globalisation describes the simultaneous process of the expansion of space to the horizon of the world and the restriction of consciousness to the here-and-now. One can therefore speak of a simultaneous explosion and implosion of space, an explosion that will result in the paradox of "glocalisation", a phenomenon whereby global consciousness and strategies are delivered at local level.

Globalisation influences the process of modernisation. According to the sociologist Pojek (1995) modernisation is determined by two forces, he calls them Modernity 1 and Modernity 2. Modernity 1 characterises the process of rationality with the attributes of order, controllability and functional differentiation. Modernity 2 describes the force of contingency, uncontrollability and de-differentiation. Both forces are connected with each other and control each other. Hermans states (2001) that post-modern authors stress only Modernity 2 when talking about a radical transformation of modernity. They do not realise that this force has been in effect since the beginning of modernisation nor do they understand that the process of rationalisation (Modernity 1) still moulds contemporary society and the shape of national states. Both forces (Modernity 1 and Modernity 2) have gained intensity by the simultaneous expansion and restriction of space through glocalisation. People realize a deeper degree of the fragmentation, adjustability and contingency of life (Modernity 2). Hermans (2001) outlines the main processes which explain the socio-cultural dynamics of both forms of modernity. Institutions are shrinking and losing control over people's behaviour and attitudes. Youth in their mid teens are typically alienated from institutions, with the result that freedom of personal choice is expanding. On top of this, cultural traditions are increasingly questioned and their impact on individuals is diminishing (Roof 1999). The pluralisation of culture, religion and politics is intensified by the process of globalisation. People come into contact with "foreign traditions" and the globalized society at first gives the appearance of being 
multi-cultural. In such circumstances group norms diverge and individualisation is enhanced (Luhmann 1989). One cannot conclude that people who belong to the same religious group (Muslims, Christians etc.) share the same opinions. Yet, after this diversification of opinion, attitudes and identity, a countervailing tendency emerges and homogenisation occurs brought about by global industries. There is therefore a continual tension between young people who try to avoid homogenisation and the choice of possible identities available as a result of the symbols and products derived from globalisation. According to Hermans any satisfactory theory of community therefore has to consider the macro-economic dynamics which bring about globalisation and the societal dynamics which deliver glocalisation.

Although young people may be aware of national politics and of the way European values impinge upon their own political leaders, it is doubtful whether young people have a clear notion of globalisation apart from through their purchase of a global brands (e.g. MacDonald's or Nike) and their access to the endless space of the Internet. None of the variables in our database directly addressed globalisation or attempted to distinguish between European variables and variables derived from global capitalism. Insofar as global consciousness is mediated to young people, we suspect that this occurs through the religion since Christianity and Islam both in their own way determine the interpretation of international events. Turkish young people may feel solidarity with Muslims in other parts of the world; Christians may identify with Christian communities outside Europe. To some extent, therefore, discussion of religion is also discussion of globalisation. But, from another perspective, as we shall argue later, religion functions as a shield against other forms of change. Religious traditions claim historical continuity with their originating events and in this way provide stability, both cultural and individual.

\section{European variation}

Hofstede (2001) has analysed the difference between European societies and produced some pertinent insights. In all the European nations, there are geographically distributed power gaps related to population density and wealth. The population density of an area contributes to its quality of life, cultural offerings, educational possibilities, and so on. This is because some regions have natural disadvantages (for example, in regards to transportation routes and infrastructure). At the same time variations in population density affect the distribution of wealth. Opportunities for employment and commerce are greater in cities than in the sparsely populated countryside. Consequently taxation raises larger sums of money from urban than rural areas and, in turn, more government (i.e. tax) money is ploughed back into cities, and this further enhances the disparity between different areas of a single country. On a larger scale, the same effect is to be found between one country and the next. In addition to power gaps brought about by population distribution, there are power gaps brought about by social class differences. Class differences function by influencing personal values and communication skills and have an impact on the organisation of the family, on a child's performance at school and, later, in the world of work. The way in which power gaps are handled is of vital importance to the stability of a nation and of Europe as a whole, and many European policies can be interpreted as seeking to minimise such gaps in order to create political and economic stability. There are also unequal relationships among the European nations pertaining to the relationship of the individual to his or her society. Some societies are strongly influenced by individualism, while others are (still) collectively oriented. These differences are visible in the desire for an extended versus immediate family life, in establishing identity through social networks or through oneself, and in an orientation towards harmony or self-interest. In political life we can observe an orientation towards group opinion 
versus individual opinion, towards a state controlled economy versus a free market and towards joint values in communal living versus self-actualisation. Even so, the developing trend points in the direction of individualization. The work of Hofstede also shows other differences between societies that can be attributed to varying degrees of masculine and feminine patterns of behaviour and values. On top of this societies practise different strategies to avoid insecurities caused by foreign influences, and some nations have strong and active strategies while others have ineffective strategies.

\section{Young people's identity}

Identity questions arise when self-expression and self-actualisation are publicly criticised and when previously accepted lifestyles are devalued. During globalisation and Europeanisation questions of identity are vital, especially when they bring differences into the open and lead to public debate. When people are challenged with regard to identity, they cannot simply retreat into unthinking cycles of habit. They have to face pressing questions about what will be valid in future. The culture of a nation is itself affected by these processes and, when culture is weakened, it no longer creates the cement that holds a society together. Emile Durkheim (1857-1917) sees in culture a representation of unity. For him, culture can be equated with the values, norms, customs and patterns of behaviour that are accepted and understood by an overwhelming majority of the population. According to such a definition of culture, however, the individual is considered problematic. Questions like "Who am I?" "Where do I come from?" "Where am I going?" are culturally predefined and must therefore be culturally answered. By contrast the classic cultural notion of Johann Gottfried Herder (1744-1803) touches on the idea that a certain culture is encircled in the closed uniform life of a nation. This cultural notion features three distinguishing criteria: ethnic justification: the culture should be the culture of a people; social homogeneity: culture has the function of harmonizing living together; intercultural boundaries: culture regulates what is inside and what is outside. All three criteria are today empirically questionable, especially because cultural indicators are less and less tied to national borders. This also breaks the predominant idea of a culture as an enclosed sphere that has a central core.

The question of identity turns virulent once conventional securities get lost. But is there a connection between this feeling of security and the new, emerging Europe (cf Blossfeld 2005)? The political answer is normally positive: peace has prevailed in the new Europe for more than 50 years and only limited military conflicts have occurred. In addition, Europe creates, in economic and juridical respects, conditions for peaceful cohabitation. People who share this view will talk positively about Europe. This is one side of the coin, but there is also a darker side. To give one example: people realise that the job market changes rapidly and that planning one's life is more and more affected by external factors that cannot be controlled. Furthermore it is apparent that politics are often at a loss when confronted by these changes. In France in spring 2006, young people demonstrated for months against a bill which would in their opinion damage the security of labour relations. The French government was of the opinion that the relaxation of employment law would be necessary to help face the process of globalisation. The plan to implement a new service-directive encountered resistance as people feared low-priced/low-budget workers could replace local workers. These are only a few examples for political processes which can feed the fear of the future (Zukunftsangst). People who let themselves be affected strongly by these considerations are likely to blame the process of Europeanisation and therefore to evaluate the entire European project negatively. 


\section{Functions of religion}

An important resource for the understanding of Europe's cultural sphere is religion, more specifically, Christianity. In central Europe, the Christian religion was the force that shaped social values - it created the cultural sphere - and it still has a considerable influence (consider Catholicism in Poland and Croatia and Orthodox Christianity in Balkan countries, especially Greece). Elsewhere Christianity only fulfils the role of the last horizon of meaning and competes for existence with secular ideologies (cf Herbert 2003). When religion loses its strength to teach about community, founding symbols, and convictions, what will replace it? In the absence of clarity, identity falters. Politicians worry in this context about the "soul of Europe," and not without reason have there been considerable recent efforts to decide on a common Constitution for Europe. In this attempt the role of religion, especially Christianity, was extremely controversial. Yet questions about the role of religion can be unfolded from the side of politics as well as from the side of religion.

In the political discussion about the European Constitution the big dispute about if and how Europe should avow its Christian roots remains. The insertion of the word "God" into the Constitution was rejected by the majority, and the reference to Christianity remained vague. It seems that politics struggles with a religious legacy. There is no doubt that the Christian religion has crucially shaped the worldview of Europeans for centuries, that Christian churches have brought forward great architecture and art, that they have stimulated the legal system and ethics and many charitable institutions. The same Christian religion has also shown its destructive side. It initiated or justified wars and was used to support the suppression of minorities. Christianity had difficulty accepting modernity and its freedoms. The achievements of modernity (for example individual freedom) were won in the face of opposition from the churches.

The general degree of secularisation in Europe makes it easy for politicians to ignore the relevance of religion. The majority wants to see Europe built on the ideas of humanism rather than on the Christian religion. Yet these considerations cut both ways. If Europe is described as one anthroposphere, that is based upon shared values and convictions and in which religion is only present as a private orientation, then there is no reason to exclude 80 million Turkish Muslims, if they agree to accept the prevalent system of values. But it seems that at the moment the accession of Turkey has no majority appeal in Europe. If it is claimed that the reasons against the accession of Turkey are not associated with religion, but with cultural differences, we need to work out why this is so. The most obvious answer to this question is that in Turkish society culture and religion are nearly inseparable - as they were across Europe in the past. In other words, the clash between Turkey and the rest of Europe is a hidden clash between Islam and Christianity. It seems that religion is back on the European agenda.

Christianity presents an ambivalent picture. Christianity is represented by over 200 different denominations. They have a difficult time speaking with one language. They themselves are part of a pluralistic culture while, at the same time, trying to play a constructive role in the greater cohesion of Europe. Even so, individual Christians with important functions in public life sometimes allow voters a glimpse of their religious motivations. This does not always work well. The recommendation of the Italian government under Berlusconi's first period as prime minister to delegate the minister of culture, Buttiglione, to the European Commission failed. Buttiglione was regarded as a religious conservative having close ties to the Pope. There were worries that his Catholic values could undermine the neutrality of his political functions. Buttiglione was forced to stand down. Conservative Catholic Christians saw this as 
an example of the way Europe works against Christian religious values. Therefore, it is not surprising that religiously motivated groups appear to be facing two directions: they are not only supporting Europe, but some are also open about being against Europe. One example of this is the influential broadcasting station Radio Maria in Poland, which expresses opposition to western pluralism and argued against Poland joining the EU. Looking at Christian groups it is therefore completely unclear how they encourage young people to behave towards Europe.

Looking to the perspectives on life and religion we can assume that intellectually able adolescents between the age of 16 and 18 have some sense of the political and economic changes described above. In the study reported on below we want to investigate various attitudes and values and to see how these combine with attitudes towards the process of Europeanisation, and we want to do this with an eye to differences between adolescents living in different countries. Our research question is:

Among adolescents which personal, cultural, political and religious mindsets are connected with favourable (positive) or sceptical (negative) attitudes to the anthroposphere of Europe? Are there significant differences between adolescents of different countries?

\section{Design of the study}

Before we have a look at the empirical results, we want to illustrate the frame of the research project. First we describe the method and the sample and then we explain the measuring instruments we have used. After this we discuss several underlying assumptions.

\section{Method}

The empirical inquiry is based on an international research project entitled "Religion and Life Perspectives of Youth in Europe" (Ziebertz/Kay 2005; 2006). A questionnaire with about 350 items was used and translated into the languages of the countries where it was distributed. Most of the items were scaled using the 5-point Likert type of response format. The fieldwork took place in the participating countries in 2002-2003. After being coded and checked the analysis of data was carried out in the department of Practical Theology at the University of Würzburg by using SPSS.

\section{Sample}

The total number of respondents within the entire project is 9852. Nine countries (Croatia, Finland, Germany, the UK, The Netherlands, Poland, Ireland, Sweden and Turkey) took part in the study. Israel participated as well, but items related to Europe were excluded in the Israeli sample and so they are not considered further in this paper. As a result the sample used for the analysis and reported on below amounts to 9000 respondents. 


\begin{tabular}{lr} 
Country & \\
& \\
\hline & \\
Germany & 1925 \\
Great Britain & 1083 \\
Turkey & 901 \\
Poland & 803 \\
The Netherlands & 816 \\
Sweden & 757 \\
Finland & 588 \\
Ireland & 1065 \\
Croatia & 1064 \\
\end{tabular}

Three preliminary decisions were made about the sample: (1) the study should focus on a specific group of young people: school pupils with an average age of 16-18 who attended good academic secondary schools e.g. grammar schools (selective secondary schools), Gymnasium (Germany). The pupils who participated were those in their penultimate year of school who, with their exam results, would be entitled to study at university. These young people are likely in the future to have a social, intellectual and cultural influence on their peers and to occupy important public positions. Consequently it is reasonable to ask about the orientation of these young people towards public life, both now and with regard to the future. (2) The survey was carried out in places which can be considered regional centres in the different countries where the infrastructure is comparable. Our interest in those who will be the next generation of opinion formers was tied to the informed decision that while, on the one hand, the meaning of tradition, convention and custom is less marked in regional centres, on the other hand, there are generally fewer extremes in those centres than can be found in the big cities. (3) With this focus, a homogenisation of the respondents can be taken for granted and therefore a number of stratifying variables like age, level of education, town/country can be omitted from the study of attitudes. However it would be wrong to expect entirely homogenous answer patterns within the chosen group. Although the respondent group has a number of common characteristic features (such as age, level of education, urban location), the study does concern itself with separating individual and collective differences.

\section{Means of measurement}

The analysis is based on several instruments that have been extensively explained in other publications (Ziebertz/Kay 2005 and 2006). The questionnaire contained two parts: attitude towards life and religion. The instruments are too lengthy to be presented here individually; however their structure is explained briefly below.

This EUROPE-concept concerns the fact that European nations are growing closer together, and contains questions about the expectations or fears that young people associate with it. In the remaining countries it will be interesting to see how the political, social, economic and individual development of Europe is assessed, in particular, in comparison between East and North-West Europe. In public debate Europe can appear as an "incomprehensible bureaucratic machine" which pursues politics that are far removed from national interests and the needs of ordinary people. On the other hand it is clear that many problems today can no longer be 
solved by single nations: instead they require European or international agreement. Whether it is issues of the environment, the employment market or of peace and justice, national problems are dependant on international co-operation. This reciprocal dependence increases the demand for international communication and agreement. Furthermore laws in many European countries can no longer be passed nationally, and instead require ratification by higher European authorities. In this way Europe makes an impact on many aspects of life. The questions examined here are: how do young people experience Europe and on what does their attitude to it depend? Do young people feel sufficiently qualified to shape their future within Europe? Do they believe that they have enough resources at their disposal? Does their national background have an effect on their attitude to Europe?

The concept Europe is divided into two scales: DISADVANTAGES FOR THE INDIVIDUAL and EUROPE AS AN OPPORTUNITY. The first sub-concept addresses issues of the job market and the economy, but also culture and language and we note that it has some affinities with globalisation (for instance in reference to large economic zones). The second sub-concept expresses the hope of young people that they will gain advantages because of the EU. Their living conditions will gradually align and improve and the Euro, as a shared currency, is a symbol of growing together. Yet political-cultural factors are also relevant. The unification of Europe means that yesterday's enemies have become today's friends. Table XX contains the items in the sub-scale.

The scale is using the 5-point Likert format.

Table XX: Items of the Scale EUROPE

\section{Item no. Concept Items}

01 Disadvantage For me it will be hard to find a good workplace in a united Europe, since competition is growing.

04 DisADVANTAgE The greater the economic zones in the world become, the smaller my chances of fulfilling my personal interests become.

06 Disadvantage A united Europe will mix the cultures in such a way that no one will really know where they come from anymore.

03 DisadVAntage It is only a question of time before the languages get so blended into one another that my language will disappear.

02 OPPORTUNITY Europe growing together will open up many doors, particularly for young people.

07 OPPORTUNITY The uniting of Europe will improve the conditions of all people in the long run.

08 OPPORTUNITY I think it is very important that old European enemies now unite with one another.

05 OPPORTUNITY The introduction of the euro as a currency will help the Europeans integrate.

Answers: AS = I Agree Strongly; A = I Agree; NC = I am Not Certain; D = I Disagree; DS = I Disagree strongly 
Responses were first correlated with the following: scales of attitudes of adolescents towards life (with 7 dimensions and given, where relevant, in more detail below), value orientations (with 8 dimensions given, where relevant, in detail below), political attitudes (with 8 dimensions given, where relevant, in detail below), political action (with 3 dimensions), the trust in institutions (with 5 dimensions, and summarised below), cultural and religious plurality (with 3 dimensions), and attitude towards foreigners (xenophobia). Secondly the responses were correlated with scales of attitudes about religion. These scales include attitudes towards the churches (4 dimensions), towards worldviews (11 dimensions), towards the problem of superiority between the religions ( 4 dimensions), towards the goal of religious education (5 dimensions) and religious praxis.

The scales on life are shortened/abbreviated instruments based on extensive youth studies in Germany, which were carried out by the Shell Foundation (Deutsche Shell 2000). Most of the scales on religion are developed by the different research groups. Only statistically significant dimensions are documented in the analysis and relevant findings are reported here.

\section{Assumptions}

Adolescents, as well as the rest of the population, perceive positive and negative developments in Europe. The job market in many European countries is under pressure because companies move to places where production costs are cheaper. Adolescents are confronted with the situation that even a good education does not guarantee an adequate job. For this reason adolescents' assessment of their personal future and of their societal situation is likely to be correlated with their evaluation of Europe as a whole. Negative political and economic experiences of various kinds including worries about the future are likely to lead to a rejection of Europe. By contrast adolescents holding a positive attitude towards Europe are likely to see it as a land of possibilities, a potential source of "the good life". Here the country the interviewees come from plays a role. Adolescents from eastern European countries and potential accession countries like Croatia and Turkey may see the potential benefits more clearly than adolescents from "old" Europe. However, against this, eastern European and accession countries may fear that the economic and cultural power of Europe will threaten their long-established values and way of life.

If these adolescents are religious, they may experience European secularisation in ways that alienate them. They could ask themselves if this Europe in cultural-religious respects is "their" Europe. If these adolescents are secularised or of their religion is treated by them as a strictly private matter, they will be indifferent to secularisation and judge European events by other criteria. Eastern European adolescents and other adolescents from potential accession countries like Croatia and Turkey may have a positive attitude toward Europe from a personal point of view. They may be excited by the opportunities that joining the Union opens up. But it is also possible that Turkish adolescents will dislike secularising religious and cultural values which they perceive to be a threat to their own faith.

We assume that correlations between scales provide the basis for description. Correlations could be of causal nature, but do not need to be. ${ }^{1}$ Nonetheless causal conclusions are possible if they can be adequately justified theoretically. The theoretical sections of the paper attempt to do that.

\footnotetext{
${ }^{1}$ For instance: height and weight are correlated, but weight does not cause height.
} 


\section{$3 \quad$ Empirical Findings}

This empirical section describes the analysis of the correlations between the attitudes towards Europe and personal life perspectives.

\section{Attitudes towards Europe}

The analysis of the Europe-scale (see table 1) shows two factors. The first factor is constituted of items with positive content. Here, the opportunities which may arise throughout Europe are emphasized. The second factor comprises items in which problems are forecasted, which could arise in a growing Europe. Two of these items affect the first factor negatively. This means they describe a circumstance which can be seen as contrary to the content of the first factor. The first factor is about the economic consequences flowing from the process of Europeanisation, the dependency of the market and the movement of jobs. Both scales are sufficiently reliable and show a weak negative correlation $(\mathrm{r}=-.12 ; \mathrm{p}=.000)$, in other words both contents are weakly mutually exclusive. The approval and rejection respectively differs on a 5-point Likert scale. The mean of a Euro-sceptical attitude is 2.91 (S.D. $=.74$ ) so lies slightly in the negative half. The mean of the Euro-positive attitude is 3.55 (S.D. = .70). The semantics of the scales explains why the means are not mirrored. Interviewees can weigh the negative statements so heavily that they adopt an Anti-European attitude and still reject the positive statements. At the same time interviewees can be pro-Europeans and emphasise the bright side of Europe although without overlooking potential dangers - in this case they would agree with the positive statements about Europe and not reject the negative ones. As the following analyses are based on correlation values, they concern tendencies in the interactions. Tendencies are each directed towards a taper ratio, in this case towards a proEuropean or a Anti-European attitude. The previously comments need to be borne in mind when pro and contra is used to simplify description. The two European dimensions are the dependent variables in the following studies.

\section{National differences}

We assume that there will be differences among students of the various countries. As Hofstede (2001) pointed out, the degree of individualism versus tradition and collectivism will contribute to these differences. Collectivism can be the result of a strong connection between nationality and religion. This is more likely to be the case in Turkey and Poland than in other western secularised countries. The sample includes a third variant: some respondents belong to EU member states and others to aspirant states (Croatia and Turkey). For the sake of clarity in our analysis we will focus on the Anti-European scale. ${ }^{2}$

We identify 4 groups of countries that differ significantly (see Table 2). The Germans are most clear in their rejection of the Anti-European position, together with Finns, Swedes and Dutch young people. They reject a negative view on Europe and we can say they expect that Europe will offer a good environment and challenging opportunities for their future life. The United Kingdom and Ireland follow; their rejection of the Anti-European position is less strong - but they reject statements that Europe could be problematic. Three countries follow in the positive half of the scale with negative statements about Europe, in other words, they share the opinion that Europe has problematic aspects. First of all are Croatia and Poland: Poland is a young EU member state and parties who stir antagonism against Europe participate in Polish politics. Croatia is an aspirant and as our results show young people in

\footnotetext{
${ }^{2}$ Moreover the mean value is close to the median of the scale making it statistically appropriate to do this.
} 
Croatia are not without doubts about the benefits they will have from Europe. Both countries are traditionally Roman-Catholic and in both countries Catholicism tries to keep a traditional conservative religious outlook. Respondents in both countries agree with negative statements about Europe. Their agreement is not strong, just slightly in the positive half of the scale, but it is an agreement. This finding can confirm that traditional religiosity and a strong consciousness of national identity can belong together with opposition to Europe. The next significant difference is made by the Turkish sample. Young Turks are sceptical about benefits from Europe. In Turkey (more than in Poland) young people are strongly committed to religion (Islam) and used to celebrate their national identity. The current discussion about Europe and Islam could be a reason for caution of Turkish young people.

\section{Societal experiences and attitudes towards Europe}

In the following section we analyse attitudes towards Europe in relation to life-perspectives, values, experiences with politics, readiness for political action, pluralism and xenophobia (see Table 3).

\section{Life perspectives}

The scale life-perspective includes 7 dimensions of which 5 correlate significant with the Europe scale. A negative attitude towards Europe correlates with three dimensions: PESSIMISM is orientated towards the past and a negative view of the present and future. PRESENT represents an active relationship with the present. One's view of life is based in the present moment and one lives in the here and now. UNCERTAINTY posits that in the face of an open future, life can not often be planned. Everything that is decided today can prove to be wrong tomorrow. This belief can lead to less planning and to just "going with the flow".

A positive attitude towards Europe correlated with two dimensions. PLANNING is a positive way of dealing with the future. Young people with this attitude feel well equipped for the future. They consider themselves to be capable of managing their lives well in the future. SECURING emphasises an active way of dealing with time, in which one searches for a safe point which secures one's own identity based on the past.

These results show that both Euro-types have very different attitudes towards life. The AntiEuropeans are orientated towards the past and see their life threatened, the Pro-Europeans are orientated towards the future and are convinced that they are in control of their life. At the same time, they try to secure their life. Anti-Europeans and Pro-Europeans differ most in the dimension PlanNing. The feeling of being able to address the future - both actively and constructively - or not being able to do this, is the biggest difference between the two groups.

\section{Values}

The value-scale includes 8 dimensions of which 7 dimensions correlate significantly with the Europe scale. A negative attitude towards Europe correlates with three dimensions, known as AUTHENTICITY, MODERNITY and ATTRACTIVENESS, which all have an inner context. MODERNITY describes an outlook which implies constant need to be proficient in the latest technology. For example, this applies to computer equipment or mobile phones. ATTRACTIVENESS covers the latest trend in youthfulness. It applies to looking good, both now and in the future. AUTHENTICITY describes the latest trend in independence, to do and be able to do, what you want. Taken together, these three outlooks represent a value concept that can 
be described as "trendy." It concerns values that are aggressively portrayed in advertising. The target audience and main consumers are today's youth.

A positive attitude towards Europe is predicted by four dimensions. First the dimension AUTONOMY represents a new concept of autonomy. Confidence and independence are not understood as autarchy but as such values as standing up against majority opinion. The dimension called HUMANITY covers the worth of each individual and the responsibility to help others. More than this HUMANITY covers a person's ability to engage successfully in society and, at least, the ability to share goods and ideas with others. Two other dimensions represent "civil" values. PROFESSIONAL ORIENTATION describes the material-social aspect. Education and training for a future career is at the forefront here along with the desire for a good job and to be materially comfortable. FAMILY ORIENTATION describes the social-emotional aspect of integration and covers the desire to live in, and to have, a family. A home with a man/wife and children is therefore considered an aspirational value.

It is difficult to describe the results about values in a value-free way because the values of the Pro-European seems to be more desirable. This shows in relation to public life, concern for the family as a microstructure of society and eventually for one's one life, and in the desire for a good professional future. The values of the Anti-Europeans on the other hand are fashion-orientated and purely social and not concerned with wider societal responsibility

\section{Politics and attitudes towards Europe}

The politics-scale includes 8 dimensions of which 7 dimensions correlate significant with the Europe scale. A negative attitude towards Europe correlates with all seven dimensions. ANOMIE revolves around the issue the perception of public life and how incomprehensible young people find it. Is the "public life" a problem because it is thought to be too complicated? Young people may feel they already have enough to deal with, with the result that there is no time left to be interested in events beyond their immediate horizon. And, in any case, the condition of public life, as it is experienced by young people, seems to have no affect on their personal lives. DISTANCE focuses on attitudes to politics and political parties. It expresses the notion that politics is boring, irrelevant and a long way away. ALIENATION relates to the experience of powerlessness. The metaphor of a small wheel that has little or no effect on the machinery of society is an example of this. Equally the dimension concerns young people's perception that there is corruption in politics. INDIFFERENCE concerns young people's perceptions as to whether, and to what extent, political parties play a part in the problems that affect young people. The dimension of experienced POLARITY OF GENERATIONS concerns the failure of politicians because they are too concerned with the needs of the adult generation and as a consequence neglect the needs that young people of today will have in the future. PRIVATE SPHERE underlines the need to have a safe point in life to which one can return. And CONFORMITY includes the insight that it is good to accept the principles about how society functions, but this is the weakest correlation.

A positive attitude towards Europe is predicted by only one dimension, which is CONFORMITY. Anti-Europeans neglect the other dimensions and accept that it is necessary to conform oneself to society and public life to participate in them.

Comparing both sets of values it is evident that Anti-Europeans have a split or better, a distinctly negative, relation to the political culture of their country. This attitude is not shared by the Pro-Europeans. They blend into society without being uncritical, as the orientations of values have shown. From the perspective of European society the Anti-Europeans are a 
problem - not, because they are against Europe, but because they neither show a constructive attitude towards life nor a willingness to campaign for improvements.

In the area of politics a second scale was related to readiness for political action. Five dimensions were constructed and 2 have shown significance. A negative attitude towards Europe is correlated with two dimensions. PoliticAL ACTIVISTS are young people who express their opinion offensively and are also prepared to distribute propaganda material or to broadcast their opinions in public places. VIOLENT ACTIVISTS show the use of violence, for instance through occupying buildings or vandalism. Both dimensions correlate positively with Euro-scepticism.

A positive attitude towards Europe is correlated with one dimension that has a contradictory meaning: in general Pro-Europeans reject the notion of offensive political behaviour. ProEuropeans do not tend to belong to the group of PolitiCAL ACTIVISTS. The behavioural pattern of POLITICAL ACTIVISTS is not necessarily against the law, but the behavioural pattern of the Violent ACTIVISTS is. This shows that the Anti-Europeans are potentially willing to act in politically destructive ways. The Pro-Europeans strictly oppose this behaviour.

\section{Institutions}

The scale of trust in institutions includes 5 dimensions of which 2 correlate significantly with the Europe scale. To begin with dimensions which include a positive perspective on Europe: first REGULATORY institutions such as the police, the judiciary and the military are relevant. Second ISSUE-RELATED agencies such as human rights groups and environmental protection groups are important. Pro-Europeans value public institutions which represent order and justice in a society but they also support groups that work for central causes such as environmentalism and human or civil rights.

A negative attitude towards Europe correlates with a rejection of issue-related institutions. Euro-sceptic young people in general do not value such groups. This is the hinge, the point of interface, between the attitudes held by young people and value-bearing agencies and institutions. In short, the acceptance or rejection of two publicly relevant kinds of institutions is a demarcation line between pro- and anti-Europeans.

\section{Religious and cultural Pluralism}

The scale religious and cultural PLURALISM contains 3 dimensions with a positive, a negative and a neutral stance towards pluralism. The dimension with the positive evaluation of pluralism correlates with both attitudes towards Europe. This dimension includes five items in which the diversity of cultures, worldviews, beliefs and religions is represented.

The correlations show that pluralism is a helpful concept in visualising an important difference between the two groups. Europe-sceptics have a negative attitude towards cultural and religious pluralism while, by contrast, Pro-Europeans have their strongest correlation with the pluralism scale; this shows that the essence of Pro-Europeanism might be conceived of as the embracing of pluralism. We have already shown that Anti-Europeans have difficulties in feeling safe and that they lack a sense of certainty and a vision for their own personal future. For the Pro-Europeans we found the opposite. This explains why Anti-Europeans vote as they do. Their antipathy to pluralism is an expression - or reason - for their uncertainty. 


\section{Xenophobia}

The scale Xenophobia is a one-dimensional scale. Xenophobia refers to hostility toward foreigners. The items run as follows: foreigners who turn to crime in my country should be deported immediately; a lot of foreigners have it too good in this country; foreigners who do not want to conform to this country should not stay here; there are too many foreigners in this country, etc. Because it is a one-dimensional scale only one correlation can be reported. The result is clear: a xenophobic attitude correlates very positively with Anti-Europeanism. ProEuropeans reject xenophobia. This distinction between the pro and the Anti-European is the strongest we have reported until now. Thus pro- and anti-Europeans have diametrically opposed attitudes to foreigners, and this more than other concepts is what differentiates them.

\section{Religiosity and attitudes towards Europe}

In the following section, we analyse attitudes towards Europe in relation to religious concepts. First, the individual and public importance of the churches; second, the religious or nonreligious world view, and third, by reference to the problematic truth claims related to religions. Fourth, we examine religion institutionally through religious education in school as well as associated religious practice (see Table 4).

\section{Churches}

The scale CHURCHES IN MODERN LIFE deals with the meaning of the churches in modern life. Religious institutions are the visible expression of religion in all societies. Such institutions are physically present through their buildings or personnel and are present in the media through their statements about political or ethical problems. Two differentiations are made in the scale. The first differentiation regards the level on which the church is addressed: the micro-level, the relevance of the church for the individual, and the macro-level, the relevance of the church for society. The second differentiation regards the bias of the statement, either positive or negative.

A negative attitude towards Europe is predicted by the macro- and micro-level scales. AntiEuropeans value the churches. The voice of church leaders in public debates (concerning ethical questions, justice, solidarity, etc.) seems indispensable to Anti-Europeans. It is likely that Anti-Europeans hope the structurally conservative position of the churches will influence public debate and prevent too many social changes.

A pro-European position towards Europe is not predicted by any attitude about the churches.

\section{World views}

The scale about world views includes 11 dimensions which correlate significant with the Europe scale.

A negative attitude towards Europe is predicted by five dimensions. The first dimension explicitly contains CHRISTIAN-religious conceptions as well as their equivalents in Jewish and Muslim traditions. This is not to say that only these statements can be considered Christian, Jewish, or Muslim, but rather that the items that were used contain definite religious vocabulary from the respective traditions. In the Christian items, the description of the existence of God uses biblical terms. God is the God of the Bible, God shows himself to the world through Jesus Christ, and God speaks to each individual personally. Anti-Europeans are 
found among respondents who agree with these statements (in their Christian, Jewish or Moslem variations). In addition to their religious belief, the world view of these respondents includes humanistic ideas. In HUMANISM, the divine is reduced to the goodness of mankind, and one can claim that human beings themselves are the visible equivalent of God. Similarly in the dimension of IMMANENCE the divine can be found within oneself. Who or what God is can be seen in humans and be experienced spiritually internally. Lastly, humans are the image of God in another way. Anti-Europeans include PANTHEISM into their world view as well, which means that God and nature permeate one another reciprocally, so that God is in everything and everything is God. With this, Anti-Europeans introduce themselves as having a commitment to a particular religion and not only a free floating religiousness.

A positive attitude towards Europe is predicted by six dimensions. In the first place the dimension PRAGMATISM counts. In this scale "the meaning of life does not depend on God or a higher reality but on me myself". The individual is in the centre and "the meaning of life is to make the best out of it". The world view of the Pro-Europeans has some religious background. Therefore, the dimensions UNIVERSALISM and METATHEISM come into play. In UNIVERSALISM, there is no narrowness related to one certain religion. Religions are seen as historically contingent constructs that can speak roughly about God, but cannot grasp God himself. If there is truth, then truth is "behind" historical religions; truth is transcending religions. Similar to this holistic approach is the thinking of METATHEISM; it is impossible to express God in human terms. The main reason lies in the insurmountable rift between the narrowness of man (in his cognitive faculties, in his speech, etc.) and the greatness of God that always reaches far beyond all human terms. The religious concept of Pro-Europeans is not really connected with a "book-religion" and its institutional outlook (churches, communities). It is more an abstract philosophical idea about an "umbrella" which could cover the world. The interesting thing is that next to this religious loading of the world view of Pro-Europeans three other dimensions count. Two of them are related. In NATURALISM, it is not God, but rather Nature and her rules that are the central source of power in the world. When speaking of a higher power, then only the power of nature can be meant. This power is primordial, and cannot be traced back to any other (i.e. divine) greatness. In the concept of Cosmology, the existence of a higher power is recognized, but not in the sense of a conception of God. The higher power is the energy of the cosmos itself: it makes life possible and determines the conditions by which the world functions. Some physicists talk about an "invisible designer" and maybe this comes close to what respondents mean. It seems that this evolutionary conception can be connected with common and abstract religious ideas. There is no struggle with dogmatic or creation theology. AGNOSTIC is the last dimension that counts for Pro-Europeans. AGNOSTIC is about doubts whether the existence of religious truth can be ascertained. The doubt stands between acceptance and denial; it represents difficulty in coming to faith, which always implies a constant state of not knowing.

Both profiles can be distinguished very clearly: we identify a religious approach between tradition and syncretism among the Anti-Europeans, and a conception between an abstract religiosity and evolutionary ideas among the Pro-Europeans. The two dimensions PRAGMATISM and AGNOSTIC work in a contradictory fashion. Pro-Europeans value both dimensions, although pragmatism is a bit stronger than agnosticism. Both conceptions are rejected by the Anti-Europeans. Their world view undeniably rejects an attitude that meaning can be created by man alone and that doubt is desirable. The first position could stand for a mainstream conservative Christian (or straight Moslem position) and the second for a partly secularized independent thinking European. 


\section{Relation between religions}

The scale RELATION BETWEEN RELIGIONS contains 4 dimensions. This scale caters more specifically for the plurality between religions. Four different positions are formulated. In the framework of the confessional-religious perspective, only one's own religion is considered true. The mono-model can be described as inclusive. One still stands by one's own claims of truth, but people of other faiths can be included in this truth if they are genuinely seeking God and orienting themselves towards doing good. The insight into the narrowness of human thought, cognition, and speech leads to the inter-religious model. Within this model truth is not a given product, but one can come closer to it in a process of encountering different religions with their specific truth claims. The fourth dimension does without the term "truth", and rejects discussion of truth. From the multi-religious standpoint, all religions are the same: they have the same amount of relative value.

A negative attitude towards Europe is predicted by two dimensions. It is the mindset of an exclusivist and an inclusivist position. Respondents who are Euro-sceptical hold truth claims and see them present in their own religion. The mono-position is somewhat weaker than the confessional, but both models distinguish themselves through a limited exposure to plurality. There really is no plurality in questions of truth, because only one truth is valid-one's own. Together, with their view on cultural and religious pluralism, it makes sense that both concepts characterise the same group.

A strongly positive attitude towards Europe is predicted by the other two dimensions. ProEuropeans defend a multi-religious standpoint that all religions are the same and that they have the same amount of relative value. This could be interpreted as religious indifference, but at the same time Pro-Europeans support an inter-religious dimension which includes the existence of truth and an eschatological perspective based on a process of dialogue between religions. The inter-dimension is an active dimension. More than this, without any religious commitment religious dialogue makes no sense. It is clear that this position must be based on a positive outlook on pluralism, and it is understandable that a confessional- and a monoreligious perspective would be a difficult condition for dialogue. That is the obvious reason why Pro-Europeans refuse the confessional- and the mono-religious conception. They are not purporting to have (to own) the truth, but they discuss the truth as lying ahead of and beyond all religions. One can never have it, but can come closer only through dialogue. In the framework of this conception, inter-religiousness is a modern basis for religiousness and it is theoretically obvious that this can be combined with a universalistic and meta-theistic world view.

\section{Religious Education}

In most of the European countries religious education (RE) is a subject in school. Some countries (like the UK, Sweden and partly Finland and The Netherlands) follow a nonconfessional conception of RE. Other countries offer RE in relation to the teaching of the Churches or a specific religion (Germany, Poland, Croatia, Turkey). In the UK for instance, pedagogy is the reference discipline for RE and for the creation of various curricula. In other nations, this is allocated to the duties of theology. The models are extremely diverse (Schreiner 2000; Schreiner et.al. 2002) and a glimpse into the respective national history makes it clear how the developments occur and how the respective concepts are grounded. We can therefore only ask general questions. The measuring instrument used consists of 12 items, five of which were chosen for the analysis. Different goals were formulated for these statements: RE as a recruitment element for the church; as encouragement of faith; as learning 
about religion, as learning from religion for life; and finally as education as a form of social studies.

A negative attitude towards Europe is predicted by two dimensions. Anti-Europeans prefer $\mathrm{RE}$ as an introduction into faith and into religion which is (in Christianity) a church-based teaching. This is a clear position. We can assume that it is mainly believers who subscribe to these goals as desirable objectives of RE.

A positive attitude towards Europe is predicted by three dimensions. Pro-Europeans prefer a concept of RE which is oriented around society and life. RE should make students members of a social community and share with them principles and values of how to live together. It is seen as a task of RE to discuss societal problems and to show ways of understanding and solving them. This concept seems to be close to what is called education in citizenship (Jackson 2002; Torres 1998, 101-144). In the second place RE should support students in seeking out parameters of their personal life orientation. RE should help to clarify conceptions of life and to deal with life crises. One can also say that conceptions of confessional RE are not only based on catechism but work out the relevance of faith for living. But the difference here is that this relation to religion is missing. There is one relation to religion but this is the dimension of learning about religion - which means teaching the principles of religions without any necessity of commitment, neither by the pupils or the teachers, nor in text books.

This issue shows that the objectives of RE in relation to religious socialization are not independent of perspectives on Europe. Pro-Europeans think a general overview about religions is sufficient and Anti-Europeans want religious socialization into religion.

\section{Religious practice}

The final concept we use in this analysis deals with religious practice. The scale of religious practice encompasses numerous religious activities such as worship, participation in rituals, participation in religious groups, prayer, and others. We select only three of them and add the question concerning the degree of secularization of the family heritage.

In line with previous results, Anti-Europeans participate in religious practice. In all three cases this group gives meaning to religious services. They want to have their future children baptized and integrated into the religious community and they have a practice of praying. These religious activities are connected with the attitude that Europe is a problematic construction. The Pro-Europeans are not against religious activities, but their Pro-EU position holds no significant relation to religious practices. We constructed a measuring instrument based on the self description of students as believers and the perception of their parents as believers. The frame is based on a four-cell matrix of: (1) parents-believe and studentsbelieve, (2) parents-believe and students don't believe, (3) parents don't believe and neither do students and (4) parents don't believe but students do. In this order, the four types represent continuous religiosity, secularity in the $1^{\text {st }}$ generation, secularity in the $2^{\text {nd }}$ generation, and new-religiosity. A relation of the degree of secularity with attitudes towards Europe is given, but only for the Anti-Europeans and with a negative load. The explanation is that the stronger the respondents are against a unification of Europe, the stronger is their nonsecular position. In other words: this result underlines previous findings that the most religious group among the respondents shows a negative attitude towards Europe. For the Pro-Europeans there is no significant connection between secularity and the process of Europeanization. 


\section{$4 \quad$ Conclusion and discussion}

Our study has shown that individual, social and societal life experiences of adolescents are correlated with both positive and negative attitudes towards the process of Europeanisation. The profiles of the two groups are distinct. A sceptical attitude towards Europe feeds primarily from two sources. The first is the assessment that one's personal future life is threatened and therefore no proper life planning is possible. The second source is a negative estimation of political culture. Here, several aspects are expressed: public life is experienced as chaotic, adolescents sense a big gap between themselves and representatives of public life, they feel alienation from politics and they see themselves as losers in generational conflicts. Young people react to these perceptions by retreating into the private sphere where they want to experience the stability and order which they can not find in the public sphere. This retreat from public interests corresponds with an approval of individualistic values. In addition Eurosceptical adolescents are disposed to use violence for pursuing their interests. Such adolescents have a negative attitude towards pluralistic society and hold xenophobic attitudes.

The Pro-Europeans hold directly contrary opinions in most dimensions. It rejects xenophobia, appreciates societal pluralism and rejects political activism. Adolescents in this group have, with regard to their personal life perspectives, the confidence that they can plan their life and future meaningfully. These adolescents also differ from the first group through their estimation of the political sphere. They do not share the negative assessment towards institutions of public life (like the courts and the police) and they approve of the commitment of transnational groups like Amnesty International or Greenpeace, whose aims they share. Their personal value orientation shows responsibility for the private, social and societal areas. In comparison to the first group, these adolescents appear to be in a position to act autonomously.

Some significant differences in attitudes can be explained through the national origin of the adolescents. The variance in regard to a negative assessment of Europe is 0.6 points on the 5 point Likert scale. This difference is not large and so it can be assumed that sceptics and approvers of Europe can be found in all countries. Nonetheless, sceptics have stronger representations in Turkey, Poland and Croatia than in the other countries.

These results are relevant to the future political engagement within Europe, especially if the current generation of Euro-sceptics continues to hold its attitudes and values unchanged. Euro-sceptics show an attitude towards the public sphere and its structures that could prevent democratic participation in the future. Such a bleak prospect comes from the alienation from politics felt by Euro-sceptics and their fear of a chaotic future. These attitudes can lead to the refusal of young people to take public responsibility. In the worse case scenario Euroscepticism may lead to destructive politics of the kind that troubled Europe during the $20^{\text {th }}$ century.

Can education bring some changes? Education is definitely not the ultimate cure as long as the economy remains flat (Suárez-Orozco/Qin-Hilliard 2004). Without a buoyant economy political promises can only be phrased using terms like "reform" and "modernisation" and these may deter any sense among young people that the situation can be improved. In the end unfulfilled political promises deepen scepticism. It is not the primary task of education to compensate for political failures, even though politicians may blame the education system again and again for the economy's poor performance. Education's task is to lead people to independence and maturity by enriching them with cultural resources. These empirical results 
suggest that there is a need to enable adolescents to evaluate their situation and that of society adequately, that is, to appreciate the forces of globalisation and europeanisation on the one hand and of pluralism on the other. Equally it is important for education to empower young people so they do not feel like victims of an unchangeable situation. Eventually, too, there is a need for an intercultural pedagogy that prevents the stereotyping of foreigners as the cause of all society's problems.

While analysing the data, it was a surprising fact that the two profiles of two kinds of Europeans worked out so elegantly. More than this, with the two euro-dimensions we discovered an unexpected result. Namely, that religiosity was sharpened in a twofold way: as a traditional practice and belief and as a philosophical concept. The first was primarily represented among Euro-sceptical respondents and the second among Pro-Europeans. This is what we didn't expect in such a clear way. Therefore, it is easy to answer our research question about which religious attitudes are connected with a positive or negative outlook of Europe. Additional empirical data about the religiosity of young Europeans has shown that traditional religiosity is most prevalent in countries like Turkey and Poland, as well as partly in Croatia and on a still lower level in Ireland. We can conclude that youth in these countries more frequently share a sceptical view of Europe. On the other side, we have secularised young people, most in Sweden and the Netherlands. We found abstract and philosophically based religious concepts in countries like Germany and Finland. In this context it was not surprising that youngsters of these countries hold a positive view of Europe. To prevent a misunderstanding: this does not mean that "the" youth of the countries we mention think positively or negatively about Europe or that "the" youth has a traditional or philosophical religious concept. All the results we discuss in this paper are based on averages. This includes the fact there are always some respondents located on one pole and some on the other pole. Of course there is traditional religiosity in Western European countries like Germany. But the traditional group is small and, depending on the identifying criteria, not much bigger than 5\%. So we talk about tendencies while recognising that are groups of young people who buck their own national trends. What is the meaning of the findings? We can give some suggestions for different areas.

For politicians this result could lead in different directions. Those who prefer a Europe without much religion can confirm their prejudice that religion is connected with conservatism and a latent opposition to reforms. Religiosity does not offer openness and visions for a better future of Europe and traditionally religious people have fear of changes. Politicians who call themselves religious could interpret the results as a challenge to give a voice to those who feel underrepresented in Europe. For Theology as an academic discipline the result is sobering. Theologians must admit that religiosity still works out as a social force especially if it is traditionally oriented. At the same time, outside a traditional concept of religiosity there is a religious identification of people, less dogmatic, less church related, more universalistic and open for pluralism. For theology it is important to understand what happens and to build bridges for a better interplay of different religious approaches. The academic task of Practical Theology is developing theories about practice. Practical Theology wants to find out how religion works. Why is it the case that fear of change and traditional belief fit together? What happens in traditional faith communities when they practise their worship? Is it a myth that belief gives hope to people and shows they may inter-act? What is occurring within the public dimension of faith and religion? With this, religious education is challenged to pick up these results in order to work out concepts focused on religion and citizenship. Religious education takes part in the socialisation process in which both, religion and citizenship must come together. Could it be that young Europeans who feel themselves strongly involved in the process of Europeanization evaluate traditional religiosity as less 
useful, because it wants (in their interpretation) to keep boundaries and is counter-directed to pluralism? Could this be the reason that they choose a more universalistic inclusive approach, because it seems more viable to them? There are a lot of questions which cannot be answered quickly. However, in evaluating how religions function, results can stimulate further and deeper reflection into the dimensions of belief which are alive among people and which are offered by theology and religious communities.

Finally, we note that it is possible to interpret the Pro-European factor as also a proglobalisation factor. Those young people who feel confident about the opening up of Europe and see this all in terms of increased opportunity are also likely to see globalisation as a further extension of opportunity. We can deduce from table 1 and the negative loading on the item "the greater economic sense in the world become, the smaller my chances of fulfilling my personal interests become". It is a small step from being a strong pro-European to becoming an internationalist and we would argue that the evidence for global internationalism comes from the support by Pro-Europeans for human rights (Amnesty) and global environmental problems (Greenpeace). 


\section{References}

Albrow, M (1998), Abschied vom Nationalstaat, Frankfurt, Suhrkamp.

Ash, A/Nigel, T (1994), Globalization, Institutions, and Regional Development in Europe, Oxford, Oxford University Press.

Beyer P. (1994), Religion and Globalisation. London: Sage

Blossfeld, H P (2005), Globalization, Uncertainty and Youth in Society, London, Routledge.

Davies, N (1996), Europe: a history, Oxford, Oxford University Press.

Deutsche Shell (ed.), Jugend 2000. 13. Shell Jugendstudie, Opladen, Leske \& Budrich.

Ducatel, K/Webster, J/ Herrmann, W (2000), The Information Society in Europe: Work and Life in an Age of Globalization. Lanham (MD), Rowman \& Littlefield.

Friedman, T L (2006), The World is Flat: the globalised World in the Twenty-first Century, Harmondsworth, Penguin.

Herbert D. (2003), Religion and Civil Society. Aldershot: Ashgate

Hofstede, G (2001), Culture's Consequences, Comparing Values, Behaviors, Institutions, and Organizations across Nations. Thousand Oaks (CA), Sage Publications.

Jackson B. (ed.) (2002), International Perspectives on Citizenship, Education and Religious Diversity. London: Routledge \& Falmer

Scholte, J A (2000), Globalization: a Critical Introduction, New York, St Martin's Press.

Schreiner P. (ed.) (2000), Religious Education in Europe. Münster: Comenius Institute

Schreiner P. et.al. (eds.) (2002), Committed to Europe's Future. Münster: Comenius Institute

Stiglitz, J E (2003), Globalization and its Discontents, New York, W.W.Norton.

Suárez-Orozco, M M/Qin-Hilliard, D B (2004), Globalization: Culture and Education in the New Millennium, Berkeley, University of California Press.

Sykes, R/Palier, B/Prior P (2001), Globalization and European Welfare State: Challenges and Change, Basingstoke, Palgrave.

Torres C.A. (1998), Citizenship in Democracy, Education and Multiculturalism. Boston

Weber, St (2001), Globalization and the European Political Economy, New York, Columbia University Press.

Ziebertz, H G/ Kay, W K (eds.) (2005), Youth in Europe 1: An international empirical Study about Life Perspective, Münster, LIT Verlag.

Ziebertz, H G/ Kay, W K (eds.) (2006), Youth in Europe 2: An international empirical Study about Religiosity, Münster, LIT Verlag. 
The uniting of Europe will improve the conditions of all people in the long run.

Europe growing together will open up many doors, particularly for young people.

The introduction of the euro as a currency will help the Europeans integrate.

I think it is very important that old European enemies now unite with one another.

A united Europe will mix the cultures in such a way that none will really know where they come from anymore.

The greater the economic zones in the world become, the smaller my chances of fulfilling my personal interests become. -.143

It is only a question of time before the languages get so blended into one another that my language will disappear.

For me it will be hard to find a good workplace in a united Europe, since competition is growing.

Extractions: main-component-analysis. Rotation: Varimax (Kaiser)

Expl. Variance: $49 \%$; Factor Eigenvalue: 2,1 and 1,8;

Reliability (alpha) factor $1=.70$, factor $2=.67$

Table 2: Significant differences in negative attitudes towards Europe

\begin{tabular}{llllll} 
Country & $\mathrm{N}$ & 1 & 2 & 3 & 4 \\
\hline Germany & 1908 & 2.6985 & & & \\
Finland & 562 & 2.7208 & & & \\
Sweden & 712 & 2.8013 & 2.8013 & & \\
Netherlands & 806 & 2.8276 & 2.8276 & & \\
United & 859 & & 2.8764 & & \\
Kingdom & & & & & \\
Ireland & 824 & & 2.9332 & 3.0717 & \\
Croatia & 1043 & & & 3.1250 & \\
Poland & 796 & & & & 3.2924 \\
Turkey & 895 & & & .967 & 1.000 \\
Significance & & .083 & .068 & & \\
\hline
\end{tabular}

ANOVA: Scheffé-Procedure; Range of mean values: $1=$ negative; $3=$ median; $5=$ positive. 
Table 3: Europe and life Perspectives (Correlations)

\section{Anti-European Pro-European}

\begin{tabular}{|c|c|c|}
\hline \multicolumn{3}{|l|}{ Life-perspectives } \\
\hline Uncertainty & .193 & \\
\hline Present & .165 & \\
\hline Pessimism & .130 & \\
\hline Securing & & .156 \\
\hline Planning & -.133 & .156 \\
\hline \multicolumn{3}{|l|}{ Values } \\
\hline Authenticity & .220 & \\
\hline Modernity & .150 & \\
\hline Attractivity & .135 & \\
\hline Autonomy & & .237 \\
\hline Humanity & & .197 \\
\hline Professional Orientation & & .179 \\
\hline Family Orientation & & .132 \\
\hline \multicolumn{3}{|l|}{ Politics } \\
\hline Anomy & .302 & \\
\hline Distance & .273 & \\
\hline Alienation & .239 & \\
\hline Indifference & .229 & \\
\hline Polarity of Generations & .225 & \\
\hline Private Sphere & .183 & \\
\hline Conformity & .136 & .146 \\
\hline \multicolumn{3}{|l|}{ Political action } \\
\hline Ready for political activity & .194 & -.105 \\
\hline $\begin{array}{l}\text { Ready for violent activity } \\
\text { Institutions }\end{array}$ & .188 & \\
\hline Regulation institutions & & .127 \\
\hline $\begin{array}{l}\text { Issue-related organisations } \\
\text { Pluralism }\end{array}$ & -.083 & .189 \\
\hline $\begin{array}{l}\text { Pluralism is positive } \\
\text { Foreigners }\end{array}$ & -.157 & .261 \\
\hline Xenophobia & .318 & -.172 \\
\hline
\end{tabular}


Table 4: Europe and Religion (Correlations)

\begin{tabular}{|c|c|c|}
\hline & $\begin{array}{l}\text { Europe } \\
\text { negative }\end{array}$ & $\begin{array}{l}\text { Europe } \\
\text { positive }\end{array}$ \\
\hline \multicolumn{3}{|l|}{ Religious Institutions } \\
\hline Church positive micro & ,131 & \\
\hline $\begin{array}{l}\text { Church positive macro } \\
\text { World View }\end{array}$ & ,302 & \\
\hline Christian & \multicolumn{2}{|c|}{ World View } \\
\hline Humanism & $\begin{array}{l}, 193 \\
181\end{array}$ & \\
\hline Pantheism & ,173 & \\
\hline Nihilism & ,133 & \\
\hline Immanentism & ,107 & \\
\hline Pragmatism &,- 109 & ,153 \\
\hline Universalism & & ,128 \\
\hline Naturalism & &, 116 \\
\hline Metatheism & & ,107 \\
\hline Cosmology & & ,102 \\
\hline Agnosticism &,- 114 &, 100 \\
\hline \multicolumn{3}{|l|}{ Relation between } \\
\hline \multicolumn{3}{|l|}{ Religions } \\
\hline confessional & ,250 &,- 131 \\
\hline monoreligious & ,240 &,- 107 \\
\hline multireligious & & ,179 \\
\hline interreligious & & ,177 \\
\hline \multicolumn{3}{|l|}{ Religious Education } \\
\hline Education in Faith & .193 & \\
\hline Education into Religion & ,151 & \\
\hline Societal Education & & 147 \\
\hline Education for Life & & 131 \\
\hline Education about Religion & & ,108 \\
\hline \multicolumn{3}{|l|}{ Religious Practice } \\
\hline $\begin{array}{l}\text { Meaning of religious } \\
\text { service }\end{array}$ & ,139 & \\
\hline Baptism children & 134 & \\
\hline Practice of Praying & ,132 & \\
\hline Degree of secularization &,- 145 & \\
\hline
\end{tabular}

